\title{
O pintinho que nasceu quadrado, de Regina Chamlian e Helena Alexandrino, ou: a busca de um lugar para as diferenças
}

\author{
José Nicolau Gregorin Filho \\ Universidade de São Paulo
}

discussão sobre a aceitação das diferenças, sejam elas de caráter social, cultural ou sexual, tem sido muito comum como temática de livros voltados para crianças e jovens, principalmente após a promulgação da Lei de Diretrizes e Bases da Educação Nacional (Lei 9.394), de 20 de dezembro de 1996. A questão é que, para atender a esse mercado editorial impulsionado por propostas educacionais, vários livros abordam a questão de maneira a garantir a sua inclusão em planejamentos pedagógicos e, não necessariamente, tratam do tema de maneira literária ao abordarem o assunto diretamente e, em vários casos, não apresentam o mínimo traço de literariedade.

O que surpreende na obra $O$ pintinho que nasceu quadrado é exatamente o contrário. Suas autoras, por meio da construção de um universo ficcional com raízes plantadas pela fábula, enriquecem a discussão de modo a garantir múltiplas intertextualidades nas linguagens verbal e visual do livro.

A sociedade tradicional é mostrada neste contexto literário por meio da figura de um galinheiro e todos os seus aspectos discutidos de maneira metafórica: o machismo é mostrado na figura do galo na primeira página e na figura de um outro galo cuja função é ser o juiz, sendo a autoridade que organiza o galinheiro e traça o destino de suas dominadas; o ato de viver sem grandes reflexões e a vida assujeitada das classes dominadas é figurativizada no ato de botar ovos, ato esse tido como obrigação do sexo feminino. Nada pode ser questionado. Nada deve mudar a ordem estabelecida.

É nesse ponto que essa ordem social é subvertida. Uma das galinhas, Carola, que às vezes se encosta na grade do cercado e fica olhando para fora para vislumbrar outras possibilidades de vida, bota um ovo. Esse não era mais 
um ovo dentre vários que eram postos diariamente, era um ovo quadrado. $\mathrm{O}$ ato de olhar para fora do galinheiro, de ficar observando o horizonte que se abre para além dos limites do galinheiro já diz muito, significa a não-aceitação daquela realidade imposta à sua vida.

A galinha sonhadora bota um ovo quadrado. Mais do que o ato de colocar um ovo em pé, discutindo a ordem do mundo, esse ovo se mantém em pé por si mesmo. Evidentemente, isso não poderia ser aceito. As colegas de galinheiro comentam o absurdo da forma, sugerem para que se jogue fora aquilo que parecia uma aberração.

Sem aceitar qualquer uma das opiniões, a galinha resolve chocar o seu ovo quadrado e ali permanecer. Convoca-se um julgamento, chamam um galo juiz para organizar e resolvem expulsar a autora daquilo que já toma a proporção de um crime para fora dos limites do galinheiro. É o poder do macho e das instituições sociais, é a manutenção da ordem.

$\mathrm{Na}$ solidão de sua viagem, nasce o seu filho: um pintinho quadrado. Nessa caminhada, inúmeros animais que cruzam o caminho de mãe e filho zombam da aparência incomum da criatura e fica impossível de a galinha encontrar nova moradia para os dois.

Até este ponto da obra, encontram-se várias relações intertextuais, seja no plano de expressão verbal, seja no visual. Além de mostrar a rejeição pela sua própria espécie, aprofundando as discussões propostas pelo texto de Andersen, pode-se deparar com releituras de céus já pintados por grandes nomes da arte mundial na ilustração, assim como pode-se lembrar a história ancestral de uma mulher grávida e seu marido buscando abrigo para que uma criança nascesse no oriente há mais de dois mil anos.

Depois de longa caminhada, tempo em que se conheceram e tiveram a oportunidade de conversar sobre ser, parecer, aceitação e rejeição, e exaustos da longa caminha, o sono sob o céu de Van Gogh torna-se profundo e, ao abrir os olhos no dia seguinte, mãe e filho se deparam com uma visão incomum: animais simpáticos e completamente diferentes da forma tradicional. Nesse conjunto há uma tartaruga piramidal, um coelho triangular, um macaco redondo e uma girafa espiral, entre outros.

Após um alegre cumprimento, passam a admirar a beleza do pintinho quadrado e a trocar experiências de rejeição pelas quais todos do grupo passaram. Conversam sobre a sua vida em grupo e resolvem sair em busca de um 
lugar para viverem em paz e serem eles mesmos, com sua aparência nada convencional e seus próprios sonhos e desejos.

Conforme se disse anteriormente, o livro não mostra a aceitação pela própria espécie ou por um grupo convencional e reconhecido pela sociedade como em $O$ patinho feio, de Andersen, nem escancara a realidade das rejeições diárias sofridas por crianças e adultos no cotidiano de ruas, escolas e igrejas por pessoas que fogem do padrão, quer pela sua aparência, quer pela sua ousadia de olhar o mundo de maneira diversa do senso comum como a maioria dos livros lançados após a obrigatoriedade de se discutirem os temas transversais na sala de aula.

As relações intertextuais de $O$ pintinho que nasceu quadrado levam o seu leitor a rememorar personagens históricos não aceitos em sua época, exatamente por olharem para fora dos limites impostos pela sociedade, por serem diferentes, por viverem de maneira diversa daquela tida como certa.

A importância deste livro de Regina Chamlian e Helena Alexandrino está em colocar a importância da aceitação de si mesmo e o valor da busca por um lugar no mundo, um mundo que ainda precisa ser muito transformado. Os textos (verbal e visual) que constroem a obra mostram a estaticidade como elemento negativo para essa mudança: é na dinâmica do constante caminhar e na busca incansável que as diferenças podem ser aceitas.

Não se pode ficar alheio a essa caminhada, apenas no lugar de um mero observador. Não se pode impedir uma busca tão essencial e atual, e acima de tudo, tão humana!

\section{Referência Bibliográfica}

CHAMLIAN, Regina; ALEXANDRINO, Helena. O pintinho que nasceu quadrado. São Paulo: Global, 2007. 